\title{
Efektifitas Transportasi dan Lokasi Terhadap Distribusi Logistik di Wilayah Komando Armada I TNI-AL
}

\author{
Wahyu Kartikasari ${ }^{1 *}$, Daniel Setiawan², Erna Fauziah² \\ ${ }^{1}$ Magister Operasi Laut Sekolah Staf dan Komando Angkatan Laut \\ ${ }^{2}$ Sekolah Staf dan Komando Angkatan Laut (SESKOAL) \\ Jl. Ciledug Raya No 2, Kompleks Seskoal Kebayoran Lama Kota Jakarta \\ *kartikasariw59@gmail.com \\ DOI: https://doi.org/10.21107/rekayasa.v14i2.10968
}

\begin{abstract}
The delays and constraints that distribution centers have in supplying logistics that are often faced are related to transportation and transportation facilities that are not optimal, as well as the location of distribution centers to the remote Koarmada I area. In this study, an analysis of the effectiveness of the implementation of logistics distribution by a logistics distribution agency was carried out and the influence of the implementation of logistics distribution on supply performance to support the Koarmada I Marine Combat Operations. From the measurement model obtained using SEM-AMOS software on the three variables of Location, Transportation and Inventory that builds Logistic Distribution, Location variable has a high value of 0.566. This means that the effectiveness of the implementation of logistics distribution in distributing logistics supplies from the distribution center to Koarmada I is not effective. So that in order to answer the existing problems, the Indonesian Navy needs to plan the formation of a logistics supply distribution organization through organizational validation, building reserve locations that are in strategic positions, building infrastructure and managing logistics supplies in a comprehensive and integrated manner.
\end{abstract}

Keywords : distribution logistic, effectivity, location, transportation

\section{PENDAHULUAN}

Supply Chain Management merupakan manajemen dalam pengintegrasian sumbersumber yang penting dalam rangka distribusi barang atau logistik, hal ini mencakup perencanaan, pengelolaan aktivitas pengadaan logistik, organisasi manajemen yang dipergunakan hingga informasi yang dibutuhkan dan dipergunakan terkait mulai dari tempat bahan baku sampai tempat konsumsi, termasuk koordinasi serta kolaborasi dengan jaringan mitra usaha (pemasok, manufaktur, pergudangan, transportasi, distributor, retailer dan konsumen) dalam rangka memenuhi kebutuhan di Koarmada I. Sebuah jaringan distribusi terdiri dari aliran produk dari produsen ke konsumen melalui titik-titik pemindahan, pusat distribusi (lembaga yang ditunjuk) dan satuan yang mendistribusikan dalam hal ini melalui KRI. Peranan jaringan distribusi dan manajemennya merupakan hal yang sangat penting bagi TNI AL dalam

\section{Article History:}

Received: May, 19 $2021 ;$ Accepted: July, $7^{\text {th }} 2021$

Rekayasa ISSN: $2502-5325$ has been Accredited by Ristekdikti (Arjuna) Decree: No. 23/E/KPT/2019 August 8th, 2019 effective until 2023 meningkatkan distribusi logistik dan menjamin kelancaran dalam mendukung tugas operasi di Koarmada I. Dinamika lingkungan yang dikaitkan dengan rantai pasokan saat ini berkembang cepat dan memiliki tuntutan yang tinggi untuk memperpendek masa siklus distribusi logistik, mewajibkan lembaga yang ditunjuk dalam pendistribusian harus merancang ulang jaringan distribusi logistik tersebut.

Kendala yang dialami selama ini dalam mengantarkan bekal logistik ke wilayah kerja Koarmada I dianggap kurang optimal. Terlebih dengan adanya kejadian pandemic Covid-19 yang memberikan dampak dari segi kesehatan personil (Ariyoko, Syahtaria, \& Sukarno, 2020) dan ekonomi negara, membuat aliran logistik mengalami beberapa permasalahan. Akan tetapi dengan adanya peluang pembangunan Tol Laut pada masa

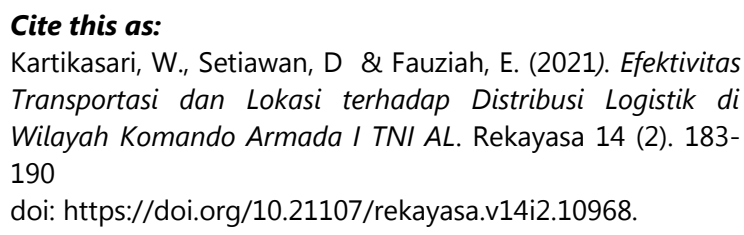


pemerintahan Presiden Jokowi, dapat diharapkan memberikan peluang dan sarana-prasarana yang dapat mendukung kegiatan distribusi logistik secara optimal. Permasalahan penelitian tersebut adalah terdapatnya keterlambatan dan kendala yang dimiliki oleh pusat distribusi dalam memasok logistik ke daerah-daerah, dimana sebagian dari jumlah daerah yang harus didukung memiliki masalah yang sering dihadapi terkait transportasi dan lokasi. Karena faktor-faktor dari permasalahan tersebut merupakan sesuatu yang dinamis sehingga untuk memininalisir permasalahan tersebut dibutuhkan fleksibilitas dari distribusi logistik demi penanganan yang efektif dan efisien dalam menghadapi setiap perubahan yang terjadi di wilayah Koarmada I. Sehingga perlu diidentifikasi dan dianalisis pengaruh dari lokasi dan transportasi terhadap Distribusi Logistik yang dilakukan oleh lembaga pendistribusi serta seberapa efektif kegiatan pemenuhan kebutuhan saat ini di wilayah Koarmada I.

Permasalahan pendistribusian logistik ke wilayah Koarmada I dapat diidentifikasi kedalam beberapa permasalahan antara lain: keterlambatan pengiriman produk, dikarenakan jarak lokasi pusat distribusi dengan Satuan Pemakai dalam hal ini Koarmada I cukup jauh; keterlambatan pengiriman produk, dikarenakan kondisi transportasi atau sarana angkut yang dimiliki oleh pusat distribusi tidak optimal dalam mendistribusikan logistik.

Adapun rumusan masalah yang diangkat dalam penelitian ini adalah bagaimana melakukan analisis efektivitas dari kegiatan distribusi oleh lembaga yang bertanggunggung jawab dalam pemenuhan logistik di dalam distribusi logistik guna mendukung Operasi Tempur Laut Koarmada I. Sedangkan tujuan penelitian dapat dirumuskan yaitu untuk menganalisis seberapa efektif dari implementasi distribusi logistik dari pusat distribusi ke Koarmada I serta untuk menganalisis hubungan pengaruh antara implementasi distribusi logistik terhadap kinerja pasokan ke Koarmada I. Dengan adanya penelitian ini diharapkan dapat menjadi masukan dan penerapan dalam pengambilan strategi dan kebijakan bagi TNI Angkatan Laut dalam mengetahui kinerja pasokan barang dari pusat distribusi ke Koarmada I.

\section{METODE PENELITIAN}

Penelitian ini merupakan penelitian eksplanatori mengenai distribusi logistik digunakan pendekatan kuantitatif dengan metode survei, menganalisis mengenai hubungan antara penerapan distribusi logistik dan pengaruhnya terhadap kinerja pasokan oleh lembaga pendistribusi. Survei yang dilakukan melalui kuesioner diberikan atau ditujukan kepada obyek penelitian, yaitu personil Koarmada I yang telah menerapkan distribusi logistik sebagai teknologi tepat guna yang telah dilaksanakan oleh lembaga pendistribusi barang logistik.

Data responden penelitian diperoleh melalui pengisian kuesioner yang telah disebarkan kepada responden yakni seluruh anggota S-Ops dan S-Log Koarmada I melalui online, dengan menggunakan google form yang telah disebar melalui media sosial. Selanjutnya data dan fakta dari angket yang terkumpul akan diuji dengan teknik analisis data SEM dengan menggunakan software AMOS 23. Dimana Tahapan analisis SEM sendiri setidaknya harus melalui lima tahapan (Byrne, 2010) yaitu: 1. spesifikasi model; 2. identifikasi model; 3. estimasi model; 4. evaluasi model; 5. modifikasi model.

\section{Variabel Penelitian}

Terdapat 2 variabel laten yang akan diukur dalam penelitian ini terdiri dari variabel bebas dan variabel terikat, yaitu

1. Variabel Bebas (Independent Variable)

a. Lokasi Strategis Pusat Distribusi : Variabel lokasi dalam penelitian ini tersusun oleh 4 (empat) indikator, yang terdiri dari Lokasi industri, perawatan gudang, upah tenaga kerja, dan kekuatan aglomerasi berdasarkan definisi lokasi industri menurut teori Losch.

b. Transportasi : Variabel transportasi dalam penelitian ini tersusun oleh 6 (enam) indikator yakni: kualitas kendaraan, tersedianya kendaraan sebagai alat angkutannya, ada jalanan/jalur yang dapat dilalui, kapasitas kendaraan, sumber daya manusia pengawak transportasi, dan organisasi atau manajemen yang menggerakkan kegiatan transportasi tersebut.

c. Persediaan Bekal : Variabel persediaan bekal dalam penelitian ini tersusun oleh 5 (lima) indikator yakni: tingkat optimal ketersediaan bekal, tingkat ketersediaan bekal di pusat distribusi, usaha memaksimalkan keuntungan dalam ketersediaan produk, rentangan untuk biaya kehabisan barang, tingkat ketersediaan produk sesuai dengan strategi.

2. Variabel Terikat (Dependent Variable) dalam penelitian ini adalah Distribusi logistik dengan 6 (enam) indikator yakni: tingkat pemenuhan 
pesanan, pengiriman sesuai due-date, pemenuhan urutan lead-time pemesanan, jumlah faktur sempurna, fleksibilitas sistem pengiriman untuk memenuhi kebutuhan pelanggan tertentu, dan produktivitas kinerja.

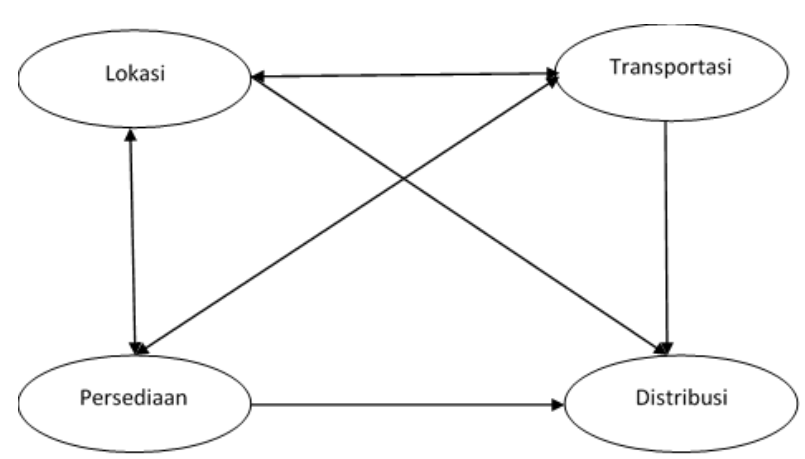

Gambar 1. Model kerangka teoritis

Adapun Konstruk - konstruk yang dibentuk dalam Kinerja distribusi logistik di Koarmada I disajikan dalam Tabel 1.

Tabel 1. Konstruk Kinerja Distribusi Logistik

\begin{tabular}{|c|c|c|}
\hline Konstruk & Indikator konstruk & Variabel \\
\hline \multirow{9}{*}{$\begin{array}{l}\text { Lokasi } \\
\text { (L) }\end{array}$} & posisi yang sangat strategis & $\mathrm{X} 11$ \\
\hline & $\begin{array}{l}\text { Layout lokasi pergudangan } \\
\text { terstandarisasi ideal }\end{array}$ & $\mathrm{X} 12$ \\
\hline & $\begin{array}{l}\text { Memiliki lokasi cadangan dalam } \\
\text { distribusi bekal logistik }\end{array}$ & $\mathrm{X} 13$ \\
\hline & $\begin{array}{l}\text { Lokasi mudah dijangkau dari sisi } \\
\text { laut }\end{array}$ & $\mathrm{X} 14$ \\
\hline & $\begin{array}{l}\text { Lokasi mudah dijangkau dari sisi } \\
\text { darat }\end{array}$ & $\mathrm{X} 15$ \\
\hline & $\begin{array}{l}\text { Lokasi mudah dijangkau dari sisi } \\
\text { udara }\end{array}$ & $\mathrm{X} 16$ \\
\hline & Perawatan terstandarisasi baik & $\mathrm{X} 17$ \\
\hline & $\begin{array}{l}\text { Personel perawatan gudang } \\
\text { sesuai SPO }\end{array}$ & $\mathrm{X} 18$ \\
\hline & $\begin{array}{l}\text { Upah kinerja sesuai dengan } \\
\text { pekerjaan dan resiko }\end{array}$ & $\mathrm{X} 19$ \\
\hline \multirow[t]{10}{*}{$\begin{array}{l}\text { Transportasi } \\
\text { (T) }\end{array}$} & $\begin{array}{l}\text { Kualitas kendaraan dan alat } \\
\text { transportasi sesuai spesifikasi }\end{array}$ & $\mathrm{X} 21$ \\
\hline & $\begin{array}{l}\text { Kualitas kendaraan dan crane } \\
\text { kondisi baik dan aman }\end{array}$ & $\mathrm{X} 22$ \\
\hline & Kapasitas angkut banyak & $\mathrm{X} 23$ \\
\hline & Kapabilitas angkut besar & $\mathrm{X} 24$ \\
\hline & $\begin{array}{l}\text { Ketersediaan kendaraan dan alat } \\
\text { transportasi dari lembaga }\end{array}$ & $\mathrm{X} 25$ \\
\hline & $\begin{array}{l}\text { Jalur distribusi dapat dilalui } \\
\text { dengan aman }\end{array}$ & $x 26$ \\
\hline & $\begin{array}{l}\text { Jalur distribusi mudah dicapai dan } \\
\text { diakses dengan pesawat udara }\end{array}$ & $\mathrm{X} 27$ \\
\hline & $\begin{array}{l}\text { Jalur distribusi mudah dicapai dan } \\
\text { diakses dengan kapal }\end{array}$ & $\mathrm{X} 28$ \\
\hline & $\begin{array}{l}\text { Jalur distribusi mudah dicapai dan } \\
\text { diakses dengan kendaraan }\end{array}$ & $\mathrm{X} 29$ \\
\hline & $\begin{array}{l}\text { Tersedia Sumber daya manusia } \\
\text { dan organisasi atau manajemen } \\
\text { transportasi }\end{array}$ & $\times 210$ \\
\hline
\end{tabular}

\begin{tabular}{|c|c|c|}
\hline Konstruk & Indikator konstruk & Variabel \\
\hline & $\begin{array}{l}\text { Memiliki sarana-prasarana untuk } \\
\text { mempermudah distribusi bekal } \\
\text { logistik }\end{array}$ & $\mathrm{X} 211$ \\
\hline \multirow[t]{5}{*}{$\begin{array}{l}\text { Persediaan } \\
\text { Bekal } \\
\text { (PB) }\end{array}$} & $\begin{array}{l}\text { Tingkat ketersediaan bekal } \\
\text { logistik sudah direncanakan dan } \\
\text { dikendalikan secara optimal }\end{array}$ & X31 \\
\hline & $\begin{array}{l}\text { Tingkat ketersediaan bekal } \\
\text { logistik di pusat distribusi sudah } \\
\text { baik }\end{array}$ & X32 \\
\hline & $\begin{array}{l}\text { Kinerja usaha dalam } \\
\text { memaksimalkan peluang dan } \\
\text { kendala pada ketersediaan bekal } \\
\text { logistik dapat diantisipasi dengan } \\
\text { segera }\end{array}$ & X33 \\
\hline & $\begin{array}{l}\text { Rentangan biaya dalam } \\
\text { menghadapi kehabisan stock } \\
\text { barang tersedia dengan baik }\end{array}$ & X34 \\
\hline & $\begin{array}{l}\text { Tingkat ketersediaan produk } \\
\text { sesuai dengan strategi } \\
\text { penyediaan }\end{array}$ & X35 \\
\hline \multirow{11}{*}{$\begin{array}{l}\text { Distribusi } \\
\text { Logistik } \\
\text { (DL) }\end{array}$} & Tingkat pemenuhan optimal & $\mathrm{Y} 1$ \\
\hline & $\begin{array}{l}\text { Proses Pengiriman sesuai waktu } \\
\text { due date }\end{array}$ & Y2 \\
\hline & $\begin{array}{l}\text { mampu melaksanakan } \\
\text { pengiriman kapasitas maksimal }\end{array}$ & Y3 \\
\hline & $\begin{array}{l}\text { Pemenuhan urutan lead-time } \\
\text { pemesanan baik }\end{array}$ & Y4 \\
\hline & $\begin{array}{l}\text { Fleksibilitas sistem pengiriman } \\
\text { baik }\end{array}$ & Y5 \\
\hline & $\begin{array}{l}\text { Produktivitas kinerja Personel } \\
\text { dalam distribusi sudah maksimal }\end{array}$ & Y6 \\
\hline & $\begin{array}{l}\text { Kinerja usaha personel } \\
\text { melaksanakan penyiapan hingga } \\
\text { pengiriman didukung } \\
\text { ketersediaan mesin dan alat/tools } \\
\text { pendukung yang lengkap }\end{array}$ & Y7 \\
\hline & $\begin{array}{l}\text { Produktivitas kinerja dari sarana } \\
\text { prasarana sudah optimal }\end{array}$ & Y8 \\
\hline & $\begin{array}{l}\text { Kinerja usaha dalam pelaksanaan } \\
\text { distribusi efektif }\end{array}$ & Y9 \\
\hline & $\begin{array}{l}\text { Kinerja usaha dalam perencanaan } \\
\text { distribusi efisien }\end{array}$ & Y10 \\
\hline & $\begin{array}{l}\text { Kinerja usaha oleh organisasi } \\
\text { menjaga mutu/kualitas dan } \\
\text { kepuasan konsumen }\end{array}$ & Y11 \\
\hline
\end{tabular}

\section{HASIL DAN PEMBAHASAN}

Logistik identik dengan organisasi, pergerakan, dan penyimpanan dari material dan manusia. Domain dari aktivitas logistik sendiri adalah menyediakan sistem dengan produk yang tepat, di lokasi yang tepat, pada waktu yang tepat dengan mengoptimasikan pengukuran performansi yang diberikan contohnya meminimalisir total biaya operasional dan memenuhi kualifikasi yang 


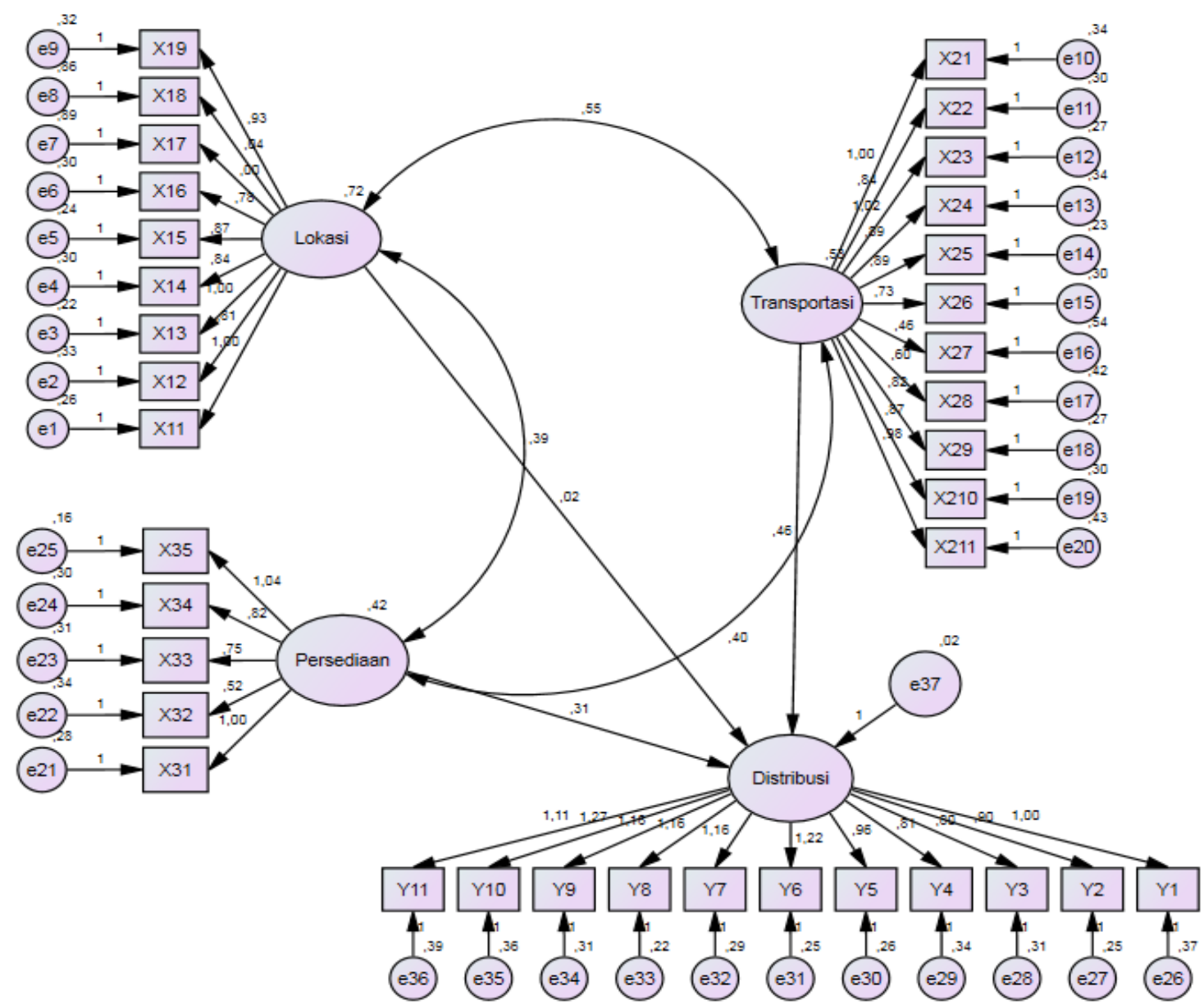

Gambar 2. Grafik Output Diagram Distribusi Logistik Model awal

diberikan sesuai dengan kemampuan dari klien dan sesuai dengan kualitas pelayanan (Rahmaningtyas et al., 2017; Soegiono, 2015). Logistik menurut Council of Supply Chain Management Professionals adalah bagian dari manajemen rantai pasok (supply chain) dalam perencanaan, pengimplementasian, dan pengontrolan aliran dan penyimpanan barang, informasi, dan pelayanan yang efektif dan efisien dari titik asal ke titik tujuan sesuai dengan permintaan konsumen (Basu, 2020).

Berdasarkan output analisis data, diperoleh hasil bahwa model kepuasan pelanggan adalah overidentified. Dengan jumlah sampel $n=122$, total jumlah data kovarian 136 sedangkan jumlah parameter yang akan diestimasi adalah 38. Dari hasil tersebut, maka degree of freedom yang dihasilkan adalah 136-38 $=98,98>0$ sehingga model tersebut overidentified, sehingga model tersebut dapat diidentifikasikan estimasinya. Model overidentified ini terjadi jika solusi yang dihasilkan tidak tunggal atau berlebih.
Tabel 1. Goodness of Fit dari Estimasi Model Awal

\begin{tabular}{llllll}
\hline No & $\begin{array}{l}\text { Goodness } \\
\text { of fit Index }\end{array}$ & $\begin{array}{l}\text { Cut of } \\
\text { Value }\end{array}$ & Kriteria & $\begin{array}{l}\text { Model } \\
\text { pertama }\end{array}$ & $\begin{array}{l}\text { Kriteria } \\
\text { hasil }\end{array}$ \\
\hline 1 & $\begin{array}{l}\text { Chi-Square } \\
\text { Probability }\end{array}$ & $\begin{array}{l}<\text { a.df } \\
>0,05\end{array}$ & Baik & 0,000 & $\begin{array}{l}\text { Kurang } \\
\text { Baik }\end{array}$ \\
\hline 2 & CMIN/DF & $<2$ & Baik & 2,264 & $\begin{array}{l}\text { Kurang } \\
\text { Baik }\end{array}$ \\
\hline 3 & GFI & $\begin{array}{l}\geq \\
0,90\end{array}$ & Baik & 0,638 & $\begin{array}{l}\text { Kurang } \\
\text { Baik }\end{array}$ \\
\hline 4 & AGFI & $\begin{array}{l}\geq \\
0,90\end{array}$ & Baik & 0,589 & $\begin{array}{l}\text { Kurang } \\
\text { Baik }\end{array}$ \\
\hline 5 & CFI & $\begin{array}{l}\geq \\
0,90\end{array}$ & Baik & 0,777 & $\begin{array}{l}\text { Kurang } \\
\text { Baik }\end{array}$ \\
\hline 6 & TLI & $\begin{array}{l}\geq \\
0,90\end{array}$ & Baik & 0,761 & $\begin{array}{l}\text { Kurang } \\
\text { Baik }\end{array}$ \\
\hline 7 & RMSEA & $\leq \begin{array}{l}\leq \\
0,08\end{array}$ & Baik & 0,102 & $\begin{array}{l}\text { Kurang } \\
\text { Baik }\end{array}$ \\
\hline
\end{tabular}

Hasil goodness of fit seperti terlihat pada tabel 2 memiliki nilai Chi-square 115,337 dengan $\mathrm{df}=2,264$ dan nilai probability adalah 0,000 yang menunjukkan bahwa model awal diketahui tidak cocok sesuai hipotesis, sehingga perlu dilakukan normalisasi data agar sesuai. Dengan melihat nilainilai yang tertera pada setiap keterkaitan variabel dapat diketahui seberapa besar pengaruh atau 


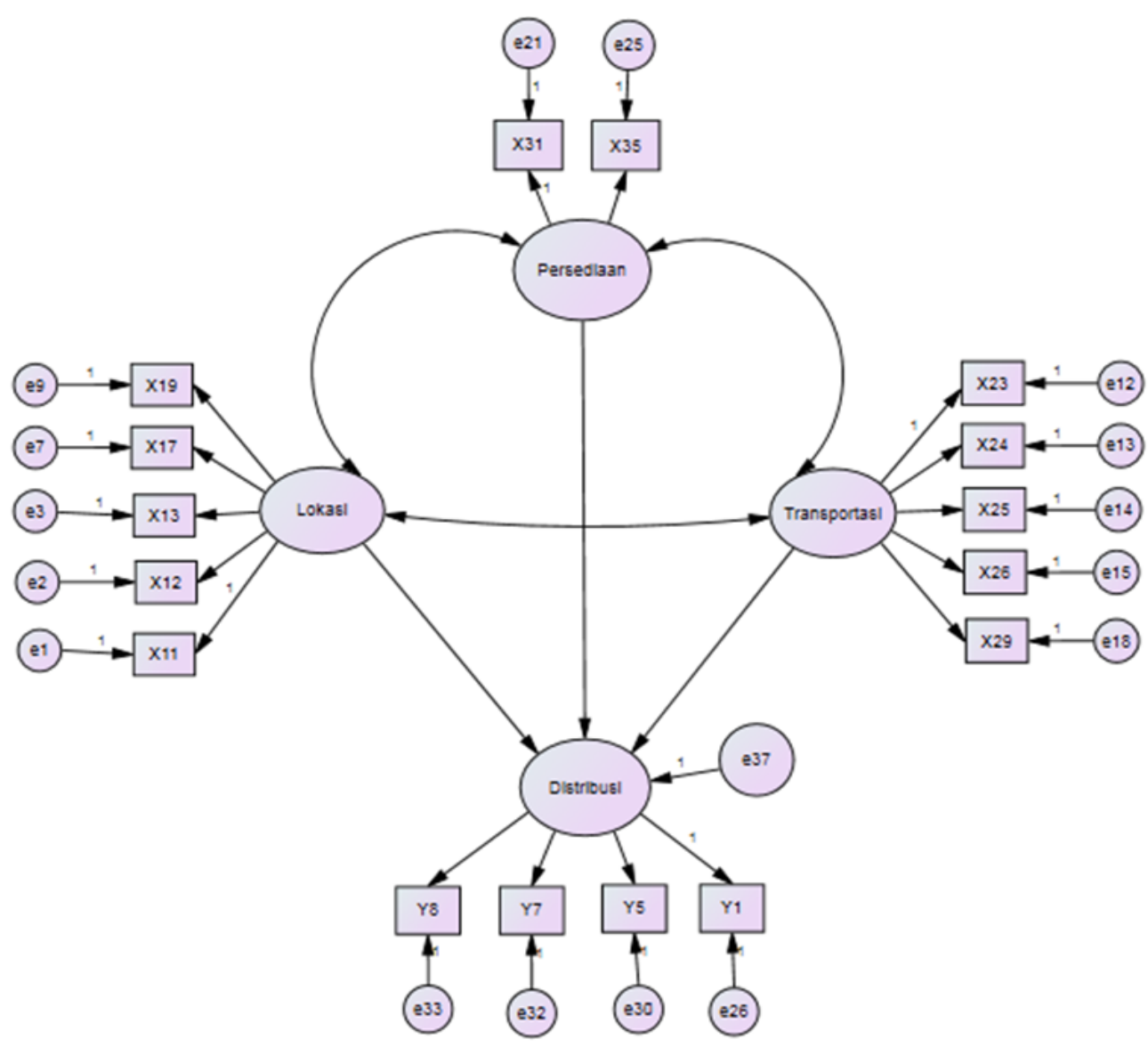

Gambar 3. Grafik Output Diagram Distribusi Logistik Model Fit

keterkaitan antara suatu variabel dengan variabel yang lain.

Tabel 2. Goodness of Fit dari Model yang Disesuaikan

\begin{tabular}{llllll}
\hline No & $\begin{array}{l}\text { Goodness of } \\
\text { fit Index }\end{array}$ & $\begin{array}{l}\text { Cut of } \\
\text { Value }\end{array}$ & Kriteria & $\begin{array}{l}\text { Fit } \\
\text { Model }\end{array}$ & $\begin{array}{l}\text { Kriteria } \\
\text { hasil }\end{array}$ \\
\hline \multirow{2}{*}{$\begin{array}{l}\text { Chi-Square } \\
\text { Probability }\end{array}$} & $\begin{array}{l}<\text { a.df } \\
>0,05\end{array}$ & Baik & 0,111 & Baik \\
\hline 2 & CMIN/DF & $<2$ & Baik & 1,17 & Baik \\
\hline 3 & GFI & $\geq 0,90$ & Baik & 0,902 & Baik \\
\hline 4 & AGFI & $\geq 0,90$ & Baik & 0,863 & Baik \\
\hline 5 & CFI & $\geq 0,90$ & Baik & 0,986 & Baik \\
\hline 6 & TLI & $\geq 0,90$ & Baik & 0,983 & Baik \\
\hline 7 & RMSEA & $\leq 0,08$ & Baik & 0,038 & Baik \\
\hline
\end{tabular}

Berdasarkan model yang telah dilakukan normalisasi data (Gambar 3), didapatkan goodness of fit yang sesuai dengan kriteria. Hal ini berarti model yang dihipotesiskan telah cocok dengan data observasi. Kecocokan model juga didukung dengan nilai GFI $=0,902$, nilai $\mathrm{TLI}=0,983$, nilai RMSEA $=0,038$. Nilai GFI dan TLI berada di atas nilai 0,9 dan nilai RMSEA berada antara interval 0,03 sampai 0,08. Sehingga model dikatakan cocok terhadap data observasi.

Tabel 3. Standardized Regression Weights

\begin{tabular}{llll}
\hline & & & Estimate \\
\hline Distribusi & $<---$ & Lokasi &, 566 \\
\hline Distribusi & $<---$ & Transportasi &, 438 \\
\hline Distribusi & $<---$ & Persediaan &, 032 \\
\hline X12 & $<---$ & Lokasi &, 783 \\
\hline X13 & $<---$ & Lokasi &, 870 \\
\hline X17 & $<---$ & Lokasi &, 003 \\
\hline X19 & $<---$ & Lokasi &, 825 \\
\hline X24 & $<---$ & Transportasi &, 777 \\
\hline$X 25$ & $<---$ & Transportasi &, 833 \\
\hline$X 26$ & $<---$ & Transportasi &, 671 \\
\hline$X 31$ & $<---$ & Persediaan &, 819 \\
\hline$X 35$ & $<---$ & Persediaan &, 846 \\
\hline$Y 5$ & $<---$ & Distribusi &, 679 \\
\hline$Y 7$ & $<---$ & Distribusi &, 776 \\
\hline$Y 8$ & $<---$ & Distribusi &, 788 \\
\hline$X 29$ & $<---$ & Transportasi &, 777 \\
\hline$X 23$ & $<---$ & Transportasi &, 841 \\
\hline$X 11$ & $<---$ & Lokasi &, 855 \\
\hline$Y 1$ & $<---$ & Distribusi &, 696 \\
\hline
\end{tabular}




\section{Uji Reliability}

Reabilitas adalah ukuran konsistensi internal dari indikator-indikator sebuah variabel bentukan yang menunjukkan derajat sampai dimana masingmasing indikator itu mengindikasikan sebuah variabel bentukan yang umum. Terdapat dua cara yang dapat digunakan, yaitu composite (construct) reliability dan variance extracted. Cut-off value dari construct reliability adalah minimal 0,70 sedangkan cut-off value untuk variance extraced minimal 0,50. Perhitungan construct reliability di atas menunjukkan bahwa seluruh dimensi dan indikator dari konstruk penelitian memiliki nilai faktor muatan standar $>0,70$ sehingga seluruhnya memiliki validitas yang baik. Perhitungan variance extraced menunjukkan bahwa seluruh dimensi dan indikator dari konstruk penelitian memiliki nilai faktor muatan standar $\geq 0,50$, sehingga seluruhnya memiliki validitas yang baik.

Intepretasi Model dalam Efisiensi Distribusi Logistik

Pemilihan model dalam pengolahan data ini memilih model alternatif metode estimasi Maximum Likelihood (ML). Pertimbangan memilih Maximum Likelihood (ML) adalah jumlah responden dalam penelitian ini sebanyak 122 orang, dimana jumlah 100 orang merupakan jumlah minimum yang disarankan hubungan antar variabel model yang didapatkan dari analisa regression of weight dapat dilihat pada Tabel 5 .

Tabel 4. Hubungan Antar Variabel

\begin{tabular}{lll}
\hline $\begin{array}{l}\text { Hubungan antar } \\
\text { variabel }\end{array}$ & $\begin{array}{l}\text { Angka } \\
\text { Korelasi }\end{array}$ & $\begin{array}{l}\text { Keterangan Besar } \\
\text { Angka Korelasi }\end{array}$ \\
\hline Distribusi dengan Lokasi & 0,566 & Tinggi \\
\hline $\begin{array}{l}\text { Distribusi dengan } \\
\text { Transportasi }\end{array}$ & 0,438 & Rendah \\
\hline $\begin{array}{l}\text { Distribusi dengan } \\
\text { Persediaan }\end{array}$ & 0,032 & Sangat Rendah \\
\hline Lokasi dengan X12 & 0,783 & Sangat Tinggi \\
\hline Lokasi dengan X13 & 0,870 & Sangat Tinggi \\
\hline Lokasi dengan X17 & 0,003 & Sangat Rendah \\
\hline Lokasi dengan X19 & 0,825 & Sangat Tinggi \\
\hline Lokasi dengan X11 & 0,855 & Sangat Tinggi \\
\hline Transportasi dengan X24 & 0,777 & Sangat Tinggi \\
\hline Transportasi dengan X25 & 0,833 & Sangat Tinggi \\
\hline Transportasi dengan X26 & 0,671 & Sangat Tinggi \\
\hline Transportasi dengan X29 & 0,777 & Sangat Tinggi \\
\hline Transportasi dengan X23 & 0,841 & Sangat Tinggi \\
\hline Persediaan dengan X31 & 0,819 & Sangat Tinggi \\
\hline Persediaan dengan X35 & 0,846 & Sangat Tinggi \\
\hline Distribusi dengan Y5 & 0,679 & Sangat Tinggi \\
\hline Distribusi dengan Y7 & 0,776 & Sangat Tinggi \\
\hline Distribusi denganY8 & 0,788 & Sangat Tinggi \\
\hline
\end{tabular}

\begin{tabular}{lll}
\hline $\begin{array}{l}\text { Hubungan antar } \\
\text { variabel }\end{array}$ & $\begin{array}{l}\text { Angka } \\
\text { Korelasi }\end{array}$ & $\begin{array}{l}\text { Keterangan Besar } \\
\text { Angka Korelasi }\end{array}$ \\
\hline Distribusi dengan Y1 & 0,696 & Sangat Tinggi \\
\hline
\end{tabular}

Dari ketiga variabel Lokasi, Transportasi dan Persediaan yang membangun Distribusi Logistik, dengan memiliki nilai muatan faktor yang sangat tinggi, yaitu variabel Lokasi sebesar 0,566. Dimana, sebagian besar responden berpendapat bahwa lokasi lembaga distribusi sangat mempengaruhi efektifitas kinerja distribusi logistik ke Koarmada I, dan selayaknya lembaga tersebut memiliki lokasi cadangan dan berada pada posisi yang sangat strategis. Hal ini terlihat bahwa nilai variabel persediaan barang terhadap distribusi logistik yang sangat rendah yakni 0,032.

Berdasarkan hasil analisis penelitian yang berdasarkan kondisi dan situasi di Koarmada I saat ini, didapatkan hasil bahwa lokasi strategis pusat distribusi, sangat berpengaruh terhadap kinerja distribusi logistik dalam memasok bekal logistik ke Koarmada I. Dengan adanya jarank lokasi yang jauh, mengakibatkan kinerja distribusi logistik tidak efektif dan berakibat pada efektifitas waktu dan efisiensi biaya.

Fungsi transportasi yang dilakukan cukup berpengaruh terhadap kinerja distribusi logistik bekal logistik untuk menjangkau Koarmada I dalam pendistribusian barang, meskipun saat ini lembaga pendistribusi logistik hanya memiliki alat transportasi darat yang sudah terstandarisasi baik sehingga hingga saat ini, masih memanfaatkan dukungan KRI yang sedang beroperasi dalam proses pendistribusian bekal logistik ke Koarmada I. Ketersedian bekal logistik di pusat distribusi memiliki pengaruh yang kurang terhadap kinerja distribusi logistik bekal logistik diabndingkan dengan variabel lainnya.

Hubungan secara keseluruhan dari variabel endogen terhadap variabel eksogen berdasarkan hasil pengujian dengan menggunakan software SEM AMOS, didapatkan bahwa Distribusi Logistik bekal logistik yang dilaksanakan oleh lembaga pendistribusi adalah tidak efektif, diakibatkan oleh jarak yang jauh, serta alat transportasi yang dimiliki hanya memiliki transportasi melalui jalur darat saja.

\section{KESIMPULAN}

Dari model pengukuran yang diperoleh, bahwa efektivitas dari implementasi distribusi logistik dalam mendistribusikan bekal logistik dari pusat distribusi ke Koarmada I tidak efektif, hal ini dikarenakan variabel transportasi yang 
dipergunakan oleh Pusat Distribusi masih didukung oleh Koarmada I, serta didukung oleh lokasi Koarmada I yang sangat jauh dari posisi Lembaga pendistribusi saat ini, maka, agar dapat efektif seyogyanya dibangun lokasi cadangan yang memiliki posisi strategis di wilayah Koarmada I.

Sehingga untuk menjawab permasalahan yang ada, TNI AL perlu merencanakan dan mengimplementasikan pembentukan organisasi lembaga pendistribusi bekal logistik di Wilayah Koarmada I melalui pembenahan dan pembentukan validasi organisasi, pembangunan sarana prasarana pendukungnya berupa gudang-gudang dan sarana angkut serta pengelolaan bekal logistik secara komprehensif dan integratif. Adapun kecepatan distribusi tidak menjadi permasalahan yang besar ketika bekal logistik tersebut digunakan dalam masa damai, akan tetapi akan berakibat fatal apabila keterlambatan itu terjadi di masa darurat atau perang.

\section{DAFTAR PUSTAKA}

Ariyoko, H. B., Syahtaria, I., \& Sukarno. (2020). Impact Design Analysis And The Effect of Pandemic Covid-19 On Personnel Readiness In Maintaining Force Combat Abilities. STTAL Postgraduate - International Conference, 4(1). Surabaya: STTAL.

Basu, A. N. (2020). Council of Supply Chain Management Professionals (CSCMP). The Grants Register 2021, 303-304. https://doi.org/10.1057/978-1-349-959884_291

Bekti, R. D., Pratiwi, N., Jatipaningrum, M. T., \& Auliana, D. (2017). Analisis Pengaruh Lokasi Dan Karakteristik Konsumen Dalam Memilih Minimarket Dengan Metode Regresi Logistik Dan Cart. Media Statistika, 10(2), 119. https://doi.org/10.14710/medstat.10.2.119-130

Byrne, B. M. (2010). Structural Equation Modeling with AMOS: Basic, Concepts, Application, and Programming. Lawrence Erlbaum Associates, Inc.

Chandra, A. (2013). Analisis Kinerja Distribusi Logistik Pada Pasokan Barang Dari Pusat Distribusi Ke Gerai Indomaret Di Kota Semarang. Fakultas Ekonomika Dan Bisnis Universitas Diponegoro Semarang.
Habibi, M. M., \& Untari, S. (2018). Efektivitas Pelaksanaan E-Procurement Dalam Pengadaan Barang Dan Jasa. Jurnal Ilmiah Pendidikan Pancasila Dan Kewarganegaraan, 3(2), 159. https://doi.org/10.17977/um019v3i2p159-168

Heizer, J., \& Render, B. (2004). Operations Management, 7th Edition. New Jersey: Pearson Education. Inc.

Hidayat. (1986). Teori Efektifitas Dalam Kinerja Karyawan. Yogyakarta: Gajah Mada University Press.

Lambert, D. M. (2016). The Eight Essential Supply Chain Management Processes. 8(6), 18-26.

Mahmudi. (2005). Manajemen Kinerja Sektor Publik. Yogyakarta: UPP AMP YKPN.

Muhammad, Y., Daoed, D., \& Syukur, M. (2017). Menggunakan Sistem Informasi Geografis. Prosiding 4th Andalas Civil Engineering (ACE) Conference 2017, November 2017, 325-334.

Nasution. (2008). Berbagai Pendekatan dalam Proses Belajar dan Mengajar. Jakarta: PT. Bumi Aksara.

Nurchana, A. R. A. (2014). Efektivitas E-Procurement Dalam Pengadaan Barang/Jasa (Studi Terhadap Penerapan E-Procurement Dalam Pengadaan Barang/Jasa Di Kabupaten Bojonegoro). Jurnal Administrasi Publik Mahasiswa Universitas Brawijaya, 2(2), 355-359.

Rahardiyanti, A. K. E. A. (2005). Evaluasi Efektivitas Sistem Informasi Manajemen dan Akuntansi Barang Milik Negara ( SIMAK-BMN ) di Departemen Kebudayaan dan Pariwisata Republik Indonesia. 5(1), 110-128.

Rahmaningtyas, W., Ismiyati, I., \& Pramusinto, H. (2017). Mengelola Manajemen Logistik dengan Efektif di Universitas Negeri Semarang. JSSH (Jurnal Sains Sosial Dan Humaniora), 1(2), 69. https://doi.org/10.30595/jssh.v1i2.1480

Robbins, S. P. (1994). Teori Organisasi: Struktur, Desain dan Aplikasi, Alih Bahasa Jusuf Udaya. Jakarta: Arcan.

Rusdiana, H. (2014). Manajemen Operasi (1st ed.). CV Pustaka Setia. http://digilib.uinsgd.ac.id/8788/1/Buku Manajemen Operasi.pdf 
Siagian, Y. M., Sitorus, F. Y., \& Malau, M. (2019). Pencatatan Persediaan dan Penetapan Harga Pokok Persediaan Pada PT Perhutani (PERSERO). Fundamental Management Journal, 4(1), 37-51.

Silaen, N. E. (2018). Model Optimasi Dalam Perencanaan Logistik Dan Rantai Suplai. 1-27. http://repositori.usu.ac.id/handle/123456789/1 0871

Soegiono, S. (2015). Faktor-Faktor Yang Mempengaruhi Kegiatan Logistik Pada Swalayan Bonnet, Papaya Dan Talia (Multiple Case Study). Jurnal Ilmiah Mahasiswa Universitas Surabaya, 4(2), 1-20.

Suharyo, O. S., Bastari, A., Ariyoko, H. B., \& Agustian, I. (2020). The Sustainability Naval Base Model using System Dynamic Methods. Senta 2018, 176-184.

https://doi.org/10.5220/0008545001760184

Villela, lucia maria aversa. (2013). Manajemen Logistik. In Journal of Chemical Information and Modeling (Vol. 53, Issue 9).
Wu, C. R., Lin, C. T., \& Chen, H. C. (2009). Integrated environmental assessment of the location selection with fuzzy analytical network process. Quality and Quantity, 43(3), 351-380. https://doi.org/10.1007/s11135-007-9125-z

Yusnita, N. (2020). Budaya Organisasi dan Efektivitas Komunikasi Antarpribadi sebagai Prediktor Komitmen Terhadap Organisasi. JIMFE (Jurnal Ilmiah Manajemen Fakultas Ekonomi), 6(2), Inpress. https://doi.org/10.34203/jimfe.v6i2.2412

Zaroni. (2015). Transportation dalam Rantai Pasok dan Logistik. Supply Chain Indonesia. http://supplychainindonesia.com/new/transport asi-dalam-rantai-pasok-dan-logistik/ 